\title{
Oil Prices and Stock Markets: Further Evidence from Newly Industrialized Countries
}

\author{
Feyyaz ZEREN ${ }^{1}$ \\ Hilmi Tunahan AKKUŞ2
}

\begin{abstract}
In this paper, the relationship between stock prices and global oil prices in newly industrialized countries (Brazil, China, India, Malaysia, Mexico, Philippines, South Africa, Thailand, Turkey and Indonesia) has been investigated. Maki Cointegration (2012) and Enders-Jones (2015) Fourier Causality Tests were used in the study including oil prices and stock market data with different start dates. While the empirical findings differ from the country to the country in terms of the cointegration relation, there is a causality mainly from stock market to oil prices.
\end{abstract}

KEYWORDS: Fourier causality, Maki cointegration, oil prices, share prices.

JEL CLASSIFICATION: $G 15, Q 02$.

\section{INTRODUCTION}

Due to increasing world population and economic developments, energy needs of the countries have been becoming greater. This increase leads to keep the energy theme up to date. Today, energy routes and corridors have become as important as trade routes in the past centuries. Despite the availability of various alternative sources such as natural gas, coal and oil to meet the energy needs of the countries, the first place of petroleum continues for now. Although the growth rate has gradually decelerated, growth in petroleum production has been still continuing (BP, 2017). Therefore, the high level of oil prices causes the macroeconomic indicators of the countries to be affected, and the volatility of the prices makes the forecasts more difficult.

One of the first studies on oil prices, Hamilton (1983) stated that there had been a striking increase in crude oil prices before the recessions since World War II (except for one), and since 1970s, when oil shocks were experienced, indicators of macroeconomic variables (growth, inflation and unemployment rate) deteriorated compared to the previous years.

Price changes in the crude oil market, the world's largest commodity market, affect economies both directly and indirectly (Maghyereh, 2004; Fatima \& Bashir, 2014). There are various transmission channels through which oil prices can influence economic indicators (Lardic \& Mignon, 2006). The first one of those is supply-side effect, which means that rising oil prices lead to an increase in the cost of production, thus reducing the amount of basic input for production and consequently decreasing output and efficiency. Second, the increase in oil prices disrupts the trade terms of oil importer countries, and leads to the transfer of wealth

\footnotetext{
${ }^{1}$ Assoc. Prof. Dr., Yalova University, Turkey, feyyaz.zeren@yalova.edu.tr (Corresponding Author)

${ }^{2}$ Dr., Balıkesir University, Turkey, tunaakkus@balikesir.edu.tr
} 
from petroleum importer countries to countries exporting oil. Thus, the purchasing power of firms in the petroleum importer countries and their families is affected negatively. Third, an increase in oil prices leads to an increase in money demand, and the failure of monetary authorities to meet rising demand decelerates economic growth and increases interest rates. Fourth, the rise in oil prices leads to inflation which might be accompanied by secondary effects resulting in a price-wage increase. Fifth, the rise in oil prices may have a negative impact on consumption, investment and stock prices. Sixth, if the increase in oil prices is permanent, production structure can change due to the adoption of new production methods with less petroleum inputs, leading to capital and labor redistribution. All these factors explain the effect of oil prices on economic indicators.

As oil, which has an important place in energy products, is a significant cost input, it directly or indirectly affects firms' profits for almost all businesses. The oil price changes affect the capital gains because the profitability situation of the enterprises has an effect on the firm value maximization which is the main aim of the financial management. Therefore, examining the relationship between oil prices and stock prices has become a subject that always draws attention. Fluctuations in oil prices affect stock prices negatively and reduce wealth and investments, increasing risks and uncertainty (Basher \& Sadorsky, 2006). Changes in oil prices must be watched closely by market actors as oil, which has significant effects on economic indicators and stock markets, is an alternative investment instrument at the same time (Abdioğlu \& Değirmenci, 2014).

The effect of increases in oil prices on stock prices can vary depending on the dependence of the firms on petroleum. However, because the number of petroleum-consuming enterprises in the world is higher than the number of petroleum-producing enterprises, it is expected that the effect of rising oil prices on the stock markets will generally be negative (Basher \& Sadorsky, 2006). Although the expectations of the impact of the increase in oil prices on the stock market are negative (Basher \& Sadorsky, 2006; Sayılgan \& Süslü, 2011), this effect may vary between countries. It might be considered that the reaction of developed and developing countries and oil importer and exporter countries to oil price changes is different.

As we have already explained, the relationship between stock returns and oil prices is often negativistic. However, as seen from the studies, it is clear that the response of the stock market to the increases in the oil prices change from market to market and time to time. The existence of a positive relationship between stock returns and oil prices for developing countries can be explained by the fact that the petroleum demand is increasing with the economic growth in the developing countries as well as the increase in stock returns due to the increase in the profits and cash flows of the firms (Le \& Chang, 2011; Sayllgan \& Süslü, 2011).

After the explanations, a review of the literature will be given, and the data and econometric methodology of this study will be explained in third part. In the following section, empirical findings will be given. In the final section, the study conclusion and suggestions will be presented.

\section{LITERATURE REVIEW}

There are many studies in the literature that investigate the relationship between oil prices and stock prices. However, the studies have generally focused on the US, Japan, Canada and the developed European countries (Jones \& Kaul, 1996; Sadorsky, 1999; Park \& Ratti, 2008); 
(Hammoudeh \& Aleisa, 2004; Arouri \& Rault, 2012; Naifar \& Al-Qaeda), countries with high economic activity such as China and India (Ono, 2011; Broadstock \& Filis, 2014; Chen, 2015) and countries exporting oil such as the Gulf Cooperation Countries (Hammoudeh \& Aleisa, 2004; Arouri \& Rault, 2012; Naifar \& Al-Dohaiman, 2013). In this study, "new industrialized countries", which have similar economic development, will be examined and the relationship between the oil prices and stock markets of these countries will be investigated.

In the literature, the relationship between oil prices and many macroeconomic variables has been the subject of many research (Hamilton, 1983; Chen, Roll \& Ross, 1986; Kaneko \& Lee, 1995). In the following studies, the relationship between oil prices and stock prices has been mainly investigated. In the pioneering work on this subject (Huang, Masulis \& Stoll, 1996; Jones \& Kaul, 1996; Sadorsky, 1999; Papapetrou, 2001), the relationship between oil prices and the general stock price indices of the countries was taken into account. However, in some studies, detailed results for each sector might be reached by comparing the oil prices with sectoral stock indexes (Faff \& Brailsford, 1999; Narayan \& Sharma, 2011; Abdioğlu \& Değirmenci, 2014). In this part, the literature studies on newly industrialized countries (Brazil, China, India, Malaysia, Mexico, Philippines, South Africa, Thailand, Turkey and Indonesia) are explained.

Maghyereh (2004) examined the dynamic relationship between the stock market index and oil prices using daily data from 1998 to 2004 on 22 developing countries. The findings of the analysis of variance involving all of the newly industrialized countries provided very poor evidence that there was a relationship between crude oil price shocks and stock market returns in developing countries.

Basher and Sadorsky (2006) studied on 21 emerging economies and MSCI (Morgan Stanley Capital International) World Index and used unconditional and conditional risk analyzes to investigate the relationship between oil price movements and stock returns. They found some strong evidence that the risk regarding the oil price affected stock price appreciation in emerging markets.

Nandha and Hammoudeh (2007) used the international factor model to examine the relationship between beta risk and realized stock exchange return for oil and exchange rate sensitivities for 15 countries in the Asia-Pacific region. The study covers 1994-2004 period and China, India, Indonesia, Malaysia, the Philippines and Thailand were also included in the study. However, only the Philippines was found to be sensitive to oil prices from these countries.

Le and Chang (2011) investigated the reactions of stock markets to volatility in oil prices during their 1986-2011 study on Japan, Singapore, South Korea and Malaysia. The study showed that the results of the causality test were not significant even though there found to be a cointegration namely long term relationship between oil prices and stock prices in Malaysia, one of the newly industrialized countries. According to the results of variance decomposition and effect-response function, stock prices were affected asymmetrically by oil prices.

Ono (2011) studied the impact of oil prices on real stock returns in the BRIC countries (Brazil, Russia, India and China) for the period 1999-2009. According to the results of the impactresponse analysis, the linear oil price shocks had no statistically significant effect on the real stock returns of Brazil and China, whereas it had a statistically significant and positive effect on the real stock indices of India and Russia. In addition, there were statistically significant 
asymmetric effects of increases and decreases in oil prices in India. Analysis of variance decomposition showed that the contribution of oil price shocks to the volatility of real stock returns for China and Russia was relatively large and statistically significant.

Sayılgan and Süslü (2011) investigated the impact of macroeconomic factors on stock returns in 11 developing countries (Turkey, Hungary, Poland, Russia, Argentina, Brazil, Chile, Mexico, Indonesia, Malaysia and Jordan). They found no statistically significant relationship between the stock returns and oil price changes.

Another detailed paper on 25 developing countries was conducted by Aloui, Nguyen and Njeh (2012). The study involving all of the newly industrialized countries showed that the oil price effect was asymmetrical to the market stages.

Basher, Haug and Sadorsky (2012) examined the dynamic relationship between oil prices, stock prices, and exchange rates of developing countries. In the study, the emerging market was measured using MSCI's emerging stock index (in US dollars) to represent stock prices. According to the results of the impact-response analysis, stock prices were responding negatively to a positive oil price shock, while oil prices were positively responding to a positive emerging market shock.

Asteriou, Dimitras and Lendewig (2013) examined the effects of fluctuations in oil prices on stock market and interest rates in oil exporting and importing countries. 18 oil importing countries and 13 oil exporting countries for the period 1988-2008 were included in the study. The newly industrialized countries; Brazil, China, India, Malaysia, Mexico, Thailand and Turkey were included in the study. Granger causality test results were examined, it was found that there was a bidirectional feedback between oil prices and stock markets in India, Brazil, Mexico, and Turkey, while there was no causality for the remaining countries. According to cointegration test results, there was a long-term relationship between the variables for China, India and Turkey. While the oil price had no effect on the stock market in Turkey, stock market had a negative effect on the oil prices. The impact of stock market on oil prices in India was positive whereas the impact of oil prices on the stock market in China and India was negative.

Le and Chang (2015) studied Singapore, Malaysia and Japan for the period 1997-2013 to examine how fluctuations in oil prices affected the stock market performance. There was no cointegration between the oil price and the Malaysian stock prices at the $1 \%$ level of significance, as a result of the cointegration test, taking structural breakdowns into account and controlling exchange rates and gold prices. Despite Malaysia being a petroleum exporting country, there was no evidence of causality at a significance level of 5\% according to the results of the causality test. According to the influence-response function, the impact of oil price shock on the stock returns for Malaysia was positive and meaningful.

The main objective of the study conducted by Abdullah, Saiti and Masih (2016) was to examine the dynamic causal relationship between the crude oil price and the Islamic stock indexes in South East Asian countries. In the study, three commodities (crude oil, gold and corn) prices of 2007-2014 period and Islamic stock index data of five countries (Malaysia, Thailand, Singapore, Philippines and Indonesia) were used. According to the findings, there was a cointegration relationship between Islamic stock indexes and crude oil. The error correction model results demonstrated that the Singapore, Philippines and Indonesian Islamic stock indexes were external, while the Malaysian and Thai Islamic stocks indexes and the 
crude oil prices were internal. This shows that the Malaysian and Thai Islamic stock indexes and crude oil prices will respond to the Singapore, Philippine and Indonesian Islamic stock indexes.

In a study conducted by Gay (2016) on BRIC countries (Brazil, Russia, India and China), the relationship between share prices, exchange rates and oil prices were examined. As a result of the study, there was no significant correlation between share prices and oil prices for BRIC countries.

Basher, Haug and Sadorsky (2012) found evidence that increasing stock prices in emerging markets were fueling oil prices. In another sectoral study, Abdioğlu and Değirmenci (2014) reached a similar conclusion. They found a unidirectional causality from stock prices to oil prices for Turkey during the period 2005-2013.

The studies mentioned up to this stage are summarized in Table 1.

In the literature, it is seen that Conventional Johansen Cointegration and Granger causality test are used to define the relationships between the variables. In this paper, with the aim of contributing to the existing literature, we have used the new generation time series methods such as the Maki cointegration test (2012), which considers multiple structural breaks in revealing the long-run relationship between variables, and the Fourier causality test developed by Enders and Jones (2015), which considers structural breaks in the smooth transition form to investigate the causality relation.

\section{ECONOMETRIC METHODOLOGY}

\subsection{Fourier ADF Unit Root and Fourier Causality Tests}

A Fourier series is an extension of a periodic $y_{t}$ function, in the form of an infinite sum of cosine and sinuses. The Fourier ADF test, developed by Enders and Lee (2012), uses trigonometric functions to capture bigger changes than the mean of the dependent variable. The advantage of this test is that it accounts for numerous temporary structural breaks with a smooth transition structure (Yılancı \& Eriş, 2013). The econometric model of this test can be explained as follows;

$$
y_{t}=\lambda_{0}+\lambda_{1} \sin \left(\frac{2 \pi k t}{T}\right)+\lambda_{2} \cos \left(\frac{2 \pi k t}{T}\right)+v_{t}
$$

where, $T$ is the sample size, $\lambda_{1}$ and $\lambda_{2}$ are the fourier coefficients, $\pi$ is 3,1416 and $k$ is the frequency used to find the optimal value that makes the sum of the residual squares least.

To perform the Fourier ADF test, first, one needs to determine $k$ which gives the least squares of residual over the model. Subsequently, critical values given in Enders and Lee's (2012) article are compared to decide whether the F-statistic obtained in this model is significant. In the final stage, the residual series of the model with selected $k$ values is created and the conventional ADF unit root test is applied to the residual series according to the linearity of the series (Anoruo \& Nwala, 2014). According to these tests, the null hypothesis expresses unit root existence and the alternative hypothesis expresses that the series is stationary (Christopoulos \& León-Ledesma, 2010).

The causality test, which detects a large number of structural breaks with a smooth transition structure, was developed by Enders and Jones (2015). The authors have investigated the standard Granger causality relation in the VAR model by adding the existence of structural breaks to the causality. Further information on aforementioned model, which has a similar econometric structure with the Fourier ADF test, can be found in the article of Enders and Jones (2015). 


\begin{tabular}{|c|c|c|c|c|}
\hline Source & Sample (Countries) & Data (Period) & Method & Empirical Findings \\
\hline Maghyereh (2004) & 22 Developing Countries & $\begin{array}{l}\text { 1998-2004 } \\
\text { (Daily) }\end{array}$ & $\begin{array}{l}\text { Variance decomposition and } \\
\text { Impulse-response function }\end{array}$ & $\mathrm{O} \neq \mathrm{S}$ \\
\hline $\begin{array}{l}\text { Basher and Sadorsky } \\
\text { (2006) }\end{array}$ & $\begin{array}{l}21 \text { Developing Countries and } \\
\text { MSCI World Index }\end{array}$ & $\begin{array}{l}\text { 1992-2005 } \\
\text { (Daily) }\end{array}$ & Multiple Regression Test & Oil prices are positively affecting stock prices. \\
\hline $\begin{array}{c}\text { Nandha and } \\
\text { Hammoudeh (2007) }\end{array}$ & $\begin{array}{l}15 \text { Countries in the Asia-Pacific } \\
\text { region }\end{array}$ & $\begin{array}{l}1994-2004 \\
\text { (Weekly) }\end{array}$ & Multiple Regression Test & $\begin{array}{l}\text { Oil prices for the Philippines are positively } \\
\text { affecting stock prices. } \mathrm{O} \neq \mathrm{S} \text { (for China, India, } \\
\text { Indonesia, Malaysia and Thailand) }\end{array}$ \\
\hline Le and Chang (2011) & $\begin{array}{l}\text { Japan, Singapore, South Korea } \\
\text { and Malaysia }\end{array}$ & $\begin{array}{l}\text { 1986-2011 } \\
\text { (Monthly) }\end{array}$ & $\begin{array}{c}\text { Johansen cointegration test and } \\
\text { Granger causality test }\end{array}$ & $\mathrm{P}=\mathrm{B}$ (Malaysia) \\
\hline Ono (2011) & BRIC Countries & $\begin{array}{l}\text { 1999-2009 } \\
\text { (Monthly) }\end{array}$ & $\begin{array}{l}\text { VAR method, Variance } \\
\text { decomposition, Impulse response } \\
\text { function }\end{array}$ & $\begin{array}{l}\text { According to the impact-response analysis, the oil } \\
\text { price shock has a positive effect on the stock } \\
\text { returns for India and Russia. }\end{array}$ \\
\hline $\begin{array}{l}\text { Sayılgan and Süslü } \\
\qquad(2011)\end{array}$ & 11 Developing Countries & $\begin{array}{c}\text { 1999-2006 } \\
\text { (Three months } \\
\text { period) }\end{array}$ & OLS & $\mathrm{O} \neq \mathrm{S}$ \\
\hline $\begin{array}{l}\text { Aloui, Nguyen and } \\
\text { Njeh (2012) }\end{array}$ & 25 Developing Countries & $\begin{array}{c}1997-2007 \\
\text { (Daily) }\end{array}$ & Rolling Regression & $\begin{array}{l}\text { The result is that the price effect of the oil is } \\
\text { asymmetrical to the market. }\end{array}$ \\
\hline $\begin{array}{l}\text { Basher, Haug and } \\
\text { Sadorsky (2012) }\end{array}$ & $\begin{array}{l}\text { MSCI Emerging Markets Share } \\
\text { Index }\end{array}$ & $\begin{array}{l}\text { 1988-2008 } \\
\text { (Monthly) }\end{array}$ & $\begin{array}{l}\text { Engle-Granger, Phillips-Ouliaris } \\
\text { and Johansen cointegration tests }\end{array}$ & $\begin{array}{r}\mathrm{O}=\mathrm{S} \\
\mathrm{S} \rightarrow \mathrm{O}\end{array}$ \\
\hline $\begin{array}{l}\text { Asteriou, Dimitras and } \\
\text { Lendewig (2013) }\end{array}$ & 18 Oil Importer Countries & $\begin{array}{l}\text { 1988-2008 } \\
\text { (Monthly) }\end{array}$ & $\begin{array}{l}\text { Johansen cointegration and Granger } \\
\text { causality test }\end{array}$ & $\begin{array}{l}\mathrm{O}=\mathrm{S} \text { (China, India and Turkey) } \\
\mathrm{O} \leftrightarrow \mathrm{S} \text { (Brazil, India, Mexico, Turkey) }\end{array}$ \\
\hline $\begin{array}{c}\text { Abdioğlu and } \\
\text { Değirmenci (2014) }\end{array}$ & Turkey & $\begin{array}{c}2005-2013 \\
\text { (Daily) }\end{array}$ & $\begin{array}{c}\text { Johansen cointegration and Granger } \\
\text { causality test }\end{array}$ & $\mathrm{S} \rightarrow \mathrm{O}$ \\
\hline Le and Chang (2015) & Japan, Singapore and Malaysia & $\begin{array}{l}1997-2013 \\
\text { (Monthly) }\end{array}$ & $\begin{array}{l}\text { Gregory-Hansen cointegration test } \\
\text { and Toda Yamamoto causality test }\end{array}$ & $\mathrm{O} \neq \mathrm{S}$ \\
\hline $\begin{array}{l}\text { Abdullah, Saiti and } \\
\text { Masih (2016) }\end{array}$ & $\begin{array}{l}\text { Malaysia, Thailand, Singapore, } \\
\text { Philippines and Indonesia }\end{array}$ & $\begin{array}{l}2007-2014 \\
\text { (Daily) }\end{array}$ & Johansen Cointegration Test & $\mathrm{O}=\mathrm{S}$ \\
\hline Gay (2016) & BRIC Countries & $\begin{array}{l}\text { 1999-2006 } \\
\text { (Monthly) }\end{array}$ & Box-Jenkins ARIMA model & $\mathrm{O} \neq \mathrm{S}$ \\
\hline
\end{tabular}

Note: O represents oil prices, and S represents stock prices. In addition, " $\rightarrow$ " indicates one-way causality relation, " $\leftrightarrow$ " indicates two-way causality relation, "=" sign indicates existence of cointegration relation and " $\neq$ " sign indicates no relation. 


\subsection{Maki Cointegration Test}

Maki (2012) criticized a Gregory-Hansen (1996) cointegration test with one structural break and Hatemi-J (2008) cointegration test with two structural break because of the preliminary determination of the number of structural breaks and suggested the cointegration test in which the number of structural breaks was determined internally. According to the basic hypothesis of this model, there is no cointegration between variables. On the other hand, the alternative hypothesis is that there is a cointegration relationship that accounts for structural breaks of which amount is determined by the model. It is stated that one of the following four models can be selected for this test:

$$
\begin{gathered}
y_{t}=\mu+\sum_{i=1}^{k} \mu_{i} D_{i, t}+\beta^{\prime} x_{t}+u_{t} \\
y_{t}=\mu+\sum_{i=1}^{k} \mu_{i} D_{i, t}+\beta^{\prime} x_{t}+\sum_{i=1}^{k} \beta^{\prime} x_{t} D_{i, t}+u_{t} \\
y_{t}=\mu+\sum_{i=1}^{k} \mu_{i} D_{i, t}+\gamma t+\beta^{\prime} x_{t}+\sum_{i=1}^{k} \beta^{\prime} x_{t} D_{i, t}+u_{t} \\
y_{t}=\mu+\sum_{i=1}^{k} \mu_{i} D_{i, t}+\gamma t+\sum \gamma_{i} t D_{i, t}+\beta^{\prime} x_{t}+\sum_{i=1}^{k} \beta^{\prime} x_{t} D_{i, t}+u_{t}
\end{gathered}
$$

In this paper, model 5, which allows changes in the level, trend and independent variables is used considering the structure of the series. The process of the Maki cointegration test is as follows; first, the selected model is estimated for every possible structural break and the unit root test statistics applied to the remains are obtained. Afterwards, the model with the least sum of residual squares in the selected models is chosen as the first breakpoint. Finally, the first structural break is included in the selected model, and the analysis continues till the number of structural breaks allowed by the researcher. The number of structural breaks in the test statistic that gives the least $\mathrm{T}$ statistic among the predicted models is selected as the appropriate break number (Y1lanc1, 2013).

\section{DATA AND EMPIRICAL FINDINGS}

In this paper, ten developing countries (Brazil, China, India, Malaysia, Mexico, Philippines, South Africa, Thailand, Turkey and Indonesia) which also called "newly industrialized countries" by IMF are included. Since an equal number of donations were not available, data from various start dates were used and the number of observations was presented in Table 2 . Most of the related works in the literature use monthly data for the analysis. In order to avoid excessive volatility and obtain more observations, monthly data is used for this study as well. The data was obtained from Yahoo's financial website (www.ukfinance.yahoo.com) and the logarithmic transforms were taken before the analysis.

Table 2. Data

\begin{tabular}{|c|c|c|c|c|c|}
\hline Stock Market & Date & Observation & Stock Market & Date & Observation \\
\hline Brazil & April 1993 & 297 & Philippines & January 1987 & 372 \\
\hline China & January 1991 & 324 & South Africa & June 1995 & 270 \\
\hline India & January 1986 & 384 & Thailand & January 1986 & 384 \\
\hline Malaysia & December 1993 & 289 & Turkey & February 1988 & 359 \\
\hline Mexico & February 1987 & 371 & Indonesia & May 1990 & 332 \\
\hline
\end{tabular}

Source: www.ukfinance.yahoo.com 
Table 3. Results of Conventional ADF Unit Root Test for Stock Markets

\begin{tabular}{|c|c|c|c|c|c|}
\hline Stock Market & Level & $\mathbf{1}^{\text {st }}$ Dif. & Stock Market & Level & $1^{\text {st }}$ Dif. \\
\hline Brazil & $-2.53(0.31)$ & $-15.00(0.00)$ & Philippines & $-2.15(0.51)$ & $-16.91(0.00)$ \\
\hline China & $-3.92(0.02)$ & $-18.51(0.00)$ & South Africa & $-2.64(0.26)$ & $-17.31(0.00)$ \\
\hline India & $-3.29(0.07)$ & $-12.78(0.00)$ & Thailand & $-2.25(0.45)$ & $-17.60(0.00)$ \\
\hline Malaysia & $-2.79(0.20)$ & $-14.85(0.00)$ & Turkey & $-1.10(0.92)$ & $-18.44(0.00)$ \\
\hline Mexico & $-3.29(0.07)$ & $-15.95(0.00)$ & Indonesia & $-3.29(0.07)$ & $-12.78(0.00)$ \\
\hline
\end{tabular}

Note: Values in parentheses refer to significance (p-value).

Source: authors

Table 4. Results of Fourier ADF Unit Root Test for Stock Markets

\begin{tabular}{|c|c|c|c|c|c|c|c|}
\hline Stock Market & $\mathbf{F}(\mathbf{k})$ & Level & $\mathbf{1}^{\text {st }}$ Dif. & Stock Market & $\mathbf{F}(\mathbf{k})$ & Level & $\mathbf{1}^{\text {st }}$ Dif. \\
\hline Brazil & 1 & $-4.21^{* *}$ & $-6.58^{* * *}$ & Philippines & 2 & -2.76 & $-5.80^{* * *}$ \\
\hline China & 1 & $-3.74 *$ & $-4.87 * * *$ & South Africa & 2 & $-3.25^{*}$ & $-7.01^{* * *}$ \\
\hline India & 2 & $-3.15^{*}$ & $-5.90^{* * *}$ & Thailand & 1 & -2.79 & $-5.50^{* * *}$ \\
\hline Malaysia & 1 & $-4.30^{* *}$ & $-4.72 * * *$ & Turkey & 1 & -3.36 & $-6.02 * * *$ \\
\hline Mexico & 2 & -2.16 & $-6.12^{* * *}$ & Indonesia & 2 & -1.44 & $-5.39 * * *$ \\
\hline
\end{tabular}

Source: authors

Note: $* * *$ and $* * *$ represent significance at $90 \%, 95 \%$, and $99 \%$ confidence levels, respectively. Critical Values are taken from study named Enders and Jones (2015) "Grain prices, oil prices, and multiple smooth breaks in a VAR".

After the introduction of the used data, the results of the unit root tests, used in determining the stationary levels of the oil prices and stock markets are presented in Table 3 and Table 4. According to the findings, conventional ADF unit root test showed that all of the series have unit roots at the level but they are stationary when the first differences of the series are taken. On the other hand, Fourier ADF test results, which take into account a large number of smooth transition structural breaks using trigonometric functions, show little differences from the conventional ADF test and has similar findings. According to Fourier ADF test, the stock market series of some countries seem to be stationary at $90 \%$ and $95 \%$ significance levels, but the findings may not be the same for $99 \%$ significance level. For this reason, taking the first differences of the time series is important to have confidence in the selection of the analysis at the next stage to obtain stable findings with $99 \%$ significance level. When the findings are evaluated for $99 \%$ significance level, all series are stationary at the first differences as if they were in the results of the conventional ADF test. Table 5 shows the results of Conventional ADF and Fourier ADF Unit Root Test for oil prices below.

Table 5. Results of Conventional ADF and Fourier ADF Unit Root Test for Oil Prices

\begin{tabular}{|c|c|c|c|c|c|}
\hline \multirow{3}{*}{ Oil Prices } & \multicolumn{2}{|c|}{ Conventional ADF Unit Root Test } & \multicolumn{3}{|c|}{ Fourier ADF Unit Root Test } \\
\cline { 2 - 6 } & Level & $\mathbf{1}^{\text {st }}$ Dif. & F (k) & Level & $\mathbf{1}^{\text {st }}$ Dif. \\
\cline { 2 - 6 } & $-2.93(0.13)$ & $-15.18(0.00)$ & 1 & -3.45 & $-6.30^{* * * *}$ \\
\hline
\end{tabular}

Note: Values in parentheses refer to significance (p-value) and *** represent significance at $99 \%$ confidence levels. Critical Values are taken from study named Enders and Jones (2015) "Grain prices, oil prices, and multiple smooth breaks in a VAR" for Fourier ADF Unit Root Tests.

In such a case that both the oil price and the stock market series are stationary in the first difference, Maki Cointegration test (2012), which considers multiple structural breaks, will provide to obtain the most accurate findings. Table 6 shows the results of the Maki Cointegration Test below. 
Table 6. Results of Maki Cointegration Test

\begin{tabular}{|c|c|c|l|}
\hline & $\begin{array}{c}\text { Test } \\
\text { Statistics }\end{array}$ & \multicolumn{1}{|c|}{ Critical Values } & \multicolumn{1}{|c|}{ Structural Break Dates } \\
\hline Brazil & $-6.25^{* * *}$ & $-6.04,-5.54,-5.58$ & July.94 \\
\hline China & -6.41 & $-7.55,-7.00,-6.71$ & July.98, Jan.05, Oct.14, Feb.16 \\
\hline India & $-6.78^{*}$ & $-7.55,-7.00,-6.71$ & Feb.92, Dec.94, April.03, May.08 \\
\hline Malaysia & $-6.32^{* * *}$ & $-6.04,-5.54,-5.58$ & March.98 \\
\hline Mexico & $-7.06^{* *}$ & $-7.55,-7.00,-6.71$ & June.92, Feb.97, Aug.98, Feb.07 \\
\hline Philippines & -6.19 & $8.00,-7.41,-7.11$ & Nov.90, Aug.92, May.94, May.02, Apr. 16 \\
\hline South Africa & -4.47 & $-6.60,-6.10,-5.84$ & Jul.98, Jan.00, \\
\hline Thailand & -6.46 & $-8.00,-7.41,-7.11$ & Feb.91, Sep.96, June.99, Mar.01, Dec. 03 \\
\hline Turkey & $-7.42^{* *}$ & $-8.00,-7.41,-7.11$ & April.90, Jul.94, Nov.96, Oct.99, Aug.04 \\
\hline Indonesia & $-6.43^{* *}$ & $-6.60,-6.10,-5.84$ & July.97, Jan.99 \\
\hline
\end{tabular}

Note: $*, * *$ and $* * *$ represent significance at 90\%, 95\%, and 99\% confidence levels, respectively. Critical Values are taken from study named Maki, D. (2012) "Tests for cointegration allowing for an unknown number of breaks".

According to the results of Maki cointegration test (2012), different findings were found for oil prices-stock market relations for different countries. Both the number of breaks and the presence of the cointegration relationships differ from country to country. Oil prices and the stock market move together in the long run for Brazil, India, Malaysia, Mexico, Turkey, and Indonesia. There was no relationship among the other countries included China, South Africa, Philippines and Thailand.

In such a case that all-time series are stationary at first difference, there is no need to use The Toda-Yamamoto (1996) causality test and its derivatives such as Hacker-Hatemi-J (2008) bootstrap causality test, Hatemi-J (2012) asymmetric causality test, used when there are different levels of stationarity in the series. In this respect, it would be appropriate to use the Fourier granger causality test developed by Enders and Jones (2015), which is intended to take into account all the structural breaks that may occur as a smooth transition. Thus, a parallel test will be used with the Fourier unit root test in the study, because both tests take into account structural breaks. The Fourier Granger causality test results are shown below.

Table 7. Results of Fourier Granger Causality Test

\begin{tabular}{|c|c|c|c|}
\hline Direction of Causality & Wald Statistics & $\begin{array}{c}\text { Asymptotic p- } \\
\text { value }\end{array}$ & $\begin{array}{c}\text { Bootstrap p- } \\
\text { value }\end{array}$ \\
\hline Oil Prices $\rightarrow$ Brazil Stock Market & 2.37 & 0.99 & 0.99 \\
\hline Brazil Stock Market $\rightarrow$ Oil Prices & 16.02 & $0.09 * * *$ & 0.11 \\
\hline Oil Prices $\rightarrow$ China Stock Market & 0.003 & 0.95 & 0.95 \\
\hline China Stock Market $\rightarrow$ Oil Prices & 2.909 & $0.08 * * *$ & $0.09 * * *$ \\
\hline Oil Prices $\rightarrow$ India Stock Market & 3.458 & 0.84 & 0.83 \\
\hline India Stock Market $\rightarrow$ Oil Prices & 20.536 & $0.005^{*}$ & $0.005^{*}$ \\
\hline Oil Prices $\rightarrow$ Malaysia Stock Market & 4.499 & 0.72 & 0.71 \\
\hline Malaysia Stock Market $\rightarrow$ Oil Prices & 18.583 & $0.009 *$ & $0.013 * *$ \\
\hline Oil Prices $\rightarrow$ Mexico Stock Market & 4.85 & 0.96 & 0.95 \\
\hline Mexico Stock Market $\rightarrow$ Oil Prices & 19.00 & $0.08 * * *$ & $0.09 * * *$ \\
\hline Oil Prices $\rightarrow$ Mexico Stock Market & 2.271 & 0.89 & 0.89 \\
\hline Mexico Stock Market $\rightarrow$ Oil Prices & 7.840 & 0.25 & 0.24 \\
\hline Oil Prices $\rightarrow$ South Africa Stock Market & 0.169 & 0.98 & 0.98 \\
\hline South Africa Stock Market $\rightarrow$ Oil Prices & 9.169 & $0.027 * *$ & $0.031 * *$ \\
\hline Oil Prices $\rightarrow$ Thailand Stock Market & 8.215 & 0.31 & 0.32 \\
\hline Thailand Stock Market $\rightarrow$ Oil Prices & 19.842 & $0.006^{*}$ & $0.007 *$ \\
\hline Oil Prices $\rightarrow$ Turkey Stock Market & 0.000 & 0.98 & 0.99 \\
\hline Turkey Stock Market $\rightarrow$ Oil Prices & 1.940 & 0.16 & 0.17 \\
\hline Oil Prices $\rightarrow$ Indonesia Stock Market & 9.088 & $0.059 * * *$ & $0.06 * * *$ \\
\hline Indonesia Stock Market $\rightarrow$ Oil Prices & 24.238 & $0.00 *$ & $0.00 *$ \\
\hline
\end{tabular}

Note: $* * *$ and $* * *$ represent significance at $90 \%, 95 \%$, and $99 \%$ confidence levels, respectively. 
According to the test results, nine of ten countries have causality relationships from stock market to oil prices. It is noteworthy that, unlike the other findings, there was no causality between the stock market and oil prices for Mexico alone. In addition, Indonesia is the only country where the relationship is from oil prices to the stock market returns. As a general conclusion, stock market prices have a serious influence on the oil prices for newly industrialized countries.

\section{CONCLUDING REMARKS}

The increase in the world population and also the economic activities of the countries lead to keep energy issue up to date in the world economy. Today, energy routes and energy corridors have become as important as trade routes in the past centuries. Despite the availability of various alternative products such as natural gas, coal and oil to meet the energy needs of the countries, the first place of petroleum continues for now. Due to the fact that oil is the most important energy source, the volatility increase in oil prices, along with the level of oil prices, affects countries and businesses from various angles. At the same time, since oil is an important investment instrument, oil prices are monitored by market actors.

The strength and direction of oil prices affecting countries are undoubtedly different depending on the countries exporting or importing oil. In addition, firms may be affected by oil price changes in different forms in the sectors. If these effects are expected to be in the negative direction in general, the opposite situation can be encountered. In this study, the long-run relationship between oil prices and stock prices was tested by the cointegration test, at the same time the direction of causality between them was investigated by causality test. Ten countries mentioned by IMF as newly industrialized countries consisting of Brazil, China, India, Malaysia, Mexico, Philippines, South Africa, Thailand, Indonesia and Turkey have been included in the scope of the study.

According to the results of the Maki cointegration test conducted firstly in the study; Brazil, India, Malaysia, Mexico, Turkey and Indonesia for oil prices and the stock market has been found to be acting together in the long term. Other countries included China, South Africa, the Philippines and Thailand no cointegration relationship was found. As known, the process of distributing deposits during the creation of a portfolio is divided between substituting investment instruments such as gold, oil, dollar and stock. In this context, the existence of a cointegration relationship between oil prices and stock prices implies that these two variables cannot be used together in portfolio diversification in terms of financial investors. Because it is not meaningful to use these two cointegrated variables together in the long term for portfolio diversification.

According to the results of the Fourier Granger causality test, which is applied secondly in the study, it is generally seen that stock markets in the included countries have a serious influence on the oil price. Contrary to expectations, this result can be explained by the fact that in the developing countries the demand for oil increases with the economic growth, and the stock prices will rise because the profits and cash flows of the companies will also increase. The causality results obtained in the study are consistent with those obtained by both Basher, Haug, Sadorsky (2012) and Abdioğlu, Değirmenci (2014). In developing countries, the use of derivatives for oil prices could be considered to reduce the possible effects of stock prices on oil prices. Thus, oil prices will be stabilized and uncertainties in future plans for financial institutions will be reduced. 
In future studies, more sophisticated findings can be obtained with tests to be done by separating positive and negative shocks by considering the presence of asymmetric information on financial markets and heterogeneity of market participants. This can be accomplished through the separation of positive and negative shocks while performing Maki cointegration and fourier causality tests. Hidden cointegration tests can be performed by creating two different series according to positive and negative shocks of the series before the cointegration test is applied. In this way, both structural breaks will be taken into consideration and the effects of positive and negative shocks will be separated. Another suggestion to be made is that the causality relation will be evaluated separately according to positive and negative shocks by means of this decomposition method. In such a case, it will be possible to talk about a new test, which is not mentioned in the literature up to now, under the name of fourier asymmetric causality test.

\section{REFERENCES}

Abdioğlu, Z. \& Değirmenci, N. (2014). Petrol fiyatlari-hisse senedi fiyatlari ilişkisi: BIST sektörel analiz. Kafkas Üniversitesi İktisadi ve İdari Bilimler Fakültesi Dergisi, 5(8), 01-24. http://dx.doi.org/10.18025/kauiibf.88612

Abdullah, A. M., Saiti, B. \& Masih, M. (2016). The impact of crude oil price on Islamic stock indices of South East Asian countries: Evidence from MGARCH-DCC and wavelet approaches. Borsa Istanbul Review, 16(24), 219-232. https://doi.org/10.1016/ j.bir.2015.12.002

Aloui, C., Nguyen, D. K. \& Njeh, H. (2012). Assessing the impacts of oil price fluctuations on stock returns in emerging markets. Economic Modelling, 29(6), 2686-2695. https://doi.org/10.1016/j.econmod.2012.08.010

Anouruo, E. and Nwala, K. (2014). Unit root properties: Interest rate swaps, Scms Journal of Indian Management, January - March

Arouri, M. H. \& Rault, C. (2012). Oil prices and stock markets in GCC countries: Empirical evidence from panel analysis. International Journal of Finance and Economics, 17(3), 242-253. https://doi.org/10.1002/ijfe.443

Asteriou, D., Dimitras, A. \& Lendewig, A. (2013). The influence of oil prices on stock market returns: Empirical evidence from oil exporting and importing countries. International Journal of Business and Management, 8(18), 101-120. http://dx.doi.org/10.5539/ ijbm.v8n18p101

Basher, A. S., Haug, A. A. \& Sadorsky, P. (2012). Oil prices, exchange rates and emerging stock markets. Energy Economics, 34(1), 227-240. https://doi.org/10.1016/ j.eneco.2011.10.005

Basher, A. S. \& Sardorsky, P. (2006). Oil price and emerging stock markets. Global Finance Journal, 17(2), 224-251. https://doi.org/10.1016/j.gfj.2006.04.001

BP (2017). BP energy outlook 2017 edition. Retrieved December 20, 2017, from https://www.bp.com/content/dam/bp/pdf/energy-economics/energy-outlook-2017/bpenergy-outlook-2017.pdf

Broadstock, D. C. \& Filis, G. (2014.). Oil price shocks and stock market returns: New evidence from the United States and China. Journal of International Financial Markets, Institutions \& Money, 33, 417-433. https://doi.org/10.1016/j.intfin.2014.09.007

Chen, N., Roll, R. \& Ross, S. (1986). Economic forces and the stock market. Journal of Business, 59(3), 383-403.

Chen, P. (2015). Global oil prices, macroeconomic fundamentals and China's commodity sector comovements. Energy Policy, 87, 284-294. https://doi.org/10.1016/ j.enpol.2015.09.024 
Christopoulos, D. K. \& León-Ledesma, M. A. (2010). Smooth breaks and non-linear mean reversion: Post-Bretton Woods real exchange rates. Journal of International Money and Finance, 29(6), 1076-1093. https://doi.org/10.1016/j.jimonfin.2010.02.003

Enders, W. \& Jones, P. (2015). Grain prices, oil prices, and multiple smooth breaks in a VAR. Studies on Nonlinear Dynamics and Econometrics. Retrieved December 20, 2017, from http://dx.doi.org/10.1515/snde-2014- 0101.

Enders, W. \&, Lee, J. (2012a). A unit root test using a fourier series to approximate smooth breaks. Oxford Bulletin of Economics and Statistics, 74(4), 574-599. https://doi.org/ 10.1111/j.1468-0084.2011.00662.x

Enders, W. \& Lee. J. (2012b). The flexible fourier form and dickey-fuller type unit root tests. Economics Letters, 117(1), 196-199. https://doi.org/10.1016/j.econlet.2012.04.081

Faff, R. \& Brailsford, T. J. (1999). Oil price risk and the Australian stock market. Journal of Energy Finance \& Development, 4(1), 69-87. https://doi.org/10.1016/S10857443(99)00005-8

Fatima, T. \& Bashir, A. (2014). Oil price and stock market fluctuations: Emerging markets (A comparative study of Pakistan and China). International Review of Management and Business Research, 3(4), 1958-1976.

Gay, R. D. Jr. (2008). Effect of macroeconomic variables on stock market returns for four emerging economies: Brazil, Russia, India and China. International Business and Economics Research Journal, 7(3), 1-8. https://doi.org/10.19030/iber.v7i3.3229

Gregory A. W., Hansen B. E. (1996). Residual-based tests for cointegration in models with regime shifts. Journal of economomics, 70, 99-126. https://doi.org/10.1016/03044076(69)41685-7

Hamilton, J. D. (1983). Oil and the macroeconomy since World War II. The Journal of Political Economy, 91(2), 228-248.

Hammoudeh, S. \& Aleisa, E. (2004). Dynamic relationships among GCC stock markets and Nymex oil futures. Contemporary Economic Policy, 22(2). 250-269. https://doi.org/10.1093/cep/byh018

Hatemi-J, A. (2008). Tests for cointegration with two unknown regime shifts with an application to financial market integration, Empirical economics, 35 (3), 497-505. https://doi.org/10.1007/s00181-007-0175-9

Huang, R. D., Masulis, R. W. \& Stoll, H. R. (1996). Energy shocks and financial markets. Journal of Futures Markets, 16(1), 1-27. https://doi.org/10.1002/(SICI)10969934(199602)16:1<1::AID-FUT1>3.0.CO;2-Q

Jones, C. M. \& Kaul, G. (1996). Oil and the stock markets. The Journal of Finance, 51(2), 463-491. https://doi.org/10.1111/j.1540-6261.1996.tb02691.x

Kaneko, T. \& Lee, B-S. (1995). Relative importance of economic factors in US and Japanese stock markets. Journal of the Japanese and International Economies, 9, 290-307. https://doi.org/10.1006/jjie.1995.1015

Lardic, S. \& Mignon, V. (2006). The impact of oil prices on GDP in European countries: An empirical investigation based on asymmetric cointegration. Energy Policy, 34(18), 3910-3915. https://doi.org/10.1016/j.enpol.2005.09.019

Le, T-H. \& Chang, Y. (2011). The impact of oil price fluctuations on stock markets in developed and emerging economies. Singapore Economic Review Conference.

Le, T-H. \& Chang, Y. (2015). Effects of oil price shocks on the stock market performance: Do nature of shocks and economies matter? Energy Economics, 51, 261-274. https://doi.org/10.1016/j.eneco.2015.06.019

Maghyereh, A. (2004). Oil price shocks and emerging stock markets: A generalized VAR approach. International Journal of Applied Econometrics and Quantitative Studies, 1(2), 27-40.

Maki, D. (2012). Tests for Cointegration Allowing for an Unknown Number of Breaks, Economic Modelling, 29, 2011-2015. https://doi.org/10.1016/j.econmod.2012.04.022 
Naifar, N. \& Al-Dohaiman, M. S. (2013). Nonlinear analysis among crude oil prices, stock markets' return and macroeconomic variables. International Review of Economics and Finance, 27, 416-431. https://doi.org/10.1016/j.iref.2013.01.001

Nandha, M. \& Hammoudeh, S. (2007). Systematic risk, and oil price and exchange rate sensitivities in Asia-Pasific stock markets. Research in International Business and Finance, 21(2), 326-341. https://doi.org/10.1016/j.ribaf.2006.09.001

Narayan, P. K. \& Sharma, S. S. (2011). New evidence on oil price and firm returns. Journal of Banking \& Finance, 35(12), 3253-3262. https://doi.org/10.1016/ j.jbankfin.2011.05.010

Ono, S. (2011). Oil price shocks and stock markets in BRICS. The European Journal of Comparative Economics, 8(1), 29-45.

Papapetrou, E. (2001). Oil price shocks, stock market, economic activity and employment in Greece. Energy Economics, 23(5), 511-532. https://doi.org/10.1016/S01409883(01)00078-0

Park, J. \& Ratti, R. A. (2008). Oil price shocks and stock markets in the U.S. and 13 European countries. Energy Economics, 30(5), 2587-2608. https://doi.org/10.1016/ j.eneco.2008.04.003

Sadorsky, P. (1999). Oil price shocks and stock market activity. Energy Economics, 21, 449469. https://doi.org/10.1016/S0140-9883(99)00020-1

Sayılgan, G. \& Süslü, C. (2011). Makroekonomik faktörlerin hisse senedi getirilerine etkisi: Türkiye ve gelişmekte olan piyasalar üzerine bir inceleme. BDDK Bankacılık ve Finansal Piyasalar Dergisi, 5(1), 73-96.

Y1lanc1, V. (2013). Financial econometrics education is given by Associate Professor Veli Y1lanc1 in 1-5 June 2013 in Sakarya University in Turkey.

Y1lanc1, V. \& Eriş, Z.A. (2013). Purchasing power parity in African countries: Further evidence from fourier unit root tests based on linear and nonlinear models. South African Journal of Economics, 81(1), 20-34. https://doi.org/10.1111/j.18136982.2012.01326.x 